\title{
Analysis of Work Capacity and Chromium Exposure on Lung Function Capacity in Metal Coating Worker
}

\author{
Ida Wahyuni $^{1, *}$, Yuliani Setyaningsih $^{1}$, Ekawati $^{1}$ \\ ${ }^{1}$ Occupational Safety and Health Departement, Faculty of Public Health, Diponegoro University, Semarang, Indonesia
}

\begin{abstract}
Chromium commonly used as an anti-corrosive agent for electroplating. Clinical and laboratory evidence showed that inhaled chromium was very toxic. Talang, Tegal have several groups of metal coating workers. As an informal sector, they have no law enforcement and also health services. The workplaces have poor hygiene sanitation, poor workplace arrangement and they tend to ignore the usage of personal protective equipment. This research aimed to analyze the work capacity and chromium exposure on lung function capacity in metal coating workers. The study population was all metal coating workers in the Talang subdistrict. While the subject of this study was purposively taken, they were consists of 35 workers that in productive age workers and do active metal coatings work. The independent variables of this study were exposure to chromium and work capacity. Dependent variable was lung function capacity. The parameters observed to find out lung function with spirometry examination. The Chi-square test were used in this research. The results showed that the levels of chromium in urine in workers averaged $21.16 \mathrm{~g} / \mathrm{L}$. There was no relationship between age, length of work, and levels of chromium in urine with lung function capacity. Nutritional status has a relationship with lung function capacity.
\end{abstract}

Keywords: levels of chromium; work capacity; forced vital capacity.

\section{Introduction}

The informal sector of metal coatings that absorb labor is electroplating or metal coating services. The electroplating technique aims to coat the metal so that it is rust-resistant and adds beauty to the shiny white color. Metal electroplating can be in the form of zinc, galvanized, silver, gold, copper, brass, nickel, and chromium. Chromium is used in various industrial processes such as stainless steel production, welding, leather tanning and metal coating [1].

Epidemiological studies show that workers exposed to chromate production and $\mathrm{Cr}$ coating have a 2-80 times risk of lung cancer [2]. Exposure to Cr (VI) in the body, especially through aerosol inhalation can cause health problems in the respiratory, carcinogenic, liver, kidney and immune system disorders. Several in-vitro studies indicate that $\mathrm{Cr}$ (III) concentrations in cells can cause DNA damage [3].

In the metal coating industry, workers are exposed to vapors, fog and $\mathrm{Cr}$ (VI) particles produced during electrolysis in a coating bath which contains chromium trioxide, sulfuric acid and various other additional organic substances [4].

The main effects associated with exposure to chromium (VI) compounds are breathing, digestion, immunology, hematology, reproduction, and growth and development. In addition, skin and eye irritation can occur due to direct contact. Based on dose-response data carried out in humans and animals, the most sensitive noncancerous effects of the compound $\mathrm{Cr}$ (VI) are breathing (nose and lung irritation, pulmonary function disorders), gastrointestinal tract (irritation, ulcers and nonneoplastic lesions of the stomach and intestines small), hematology (microcytic, hypochromic anemia), and reproduction (effects on male reproductive organs, including decreased sperm count and histopathological changes for epididymis). Intentional consumption or very high doses of chromium (VI) result in shortness of breath, cardiovascular, gastrointestinal, hematological, liver, kidney, and neurological effects as part of sequelae that cause death or in patients who survived due to medical care $[5,6]$. According to ATSDR, exposure to chromium is divided into acute exposure (14 days or less), intermediates (15 days to 1 year) and chronic exposure more than 1 year [6].

Work capacity is the ability of a worker to complete his work. The work capacity of each person is not the same and is largely determined by age, skills, physical fitness, nutrition, gender, and anthropometric measurements. Nutritional factors need to be considered especially for heavy workers, because working too heavily without adequate nutrition is often accompanied by a drastic decrease in the weight of the workers concerned. Men and women differ in their physical abilities and the strength of their muscles working and getting older is accompanied by a lack of ability to work due to changes in body organs, cardiovascular system, hormonal and others.

\footnotetext{
*Corresponding author: wahyuni_ida23@yahoo.co.id
} 
Work capacity, workload and factors of the work environment must be sought harmoniously so that dynamic balance is achieved so as to benefit the health of the workforce. If this condition is not favorable for the health of the workforce it will result in the emergence of disruption of work power, fatigue, health problems, work diseases, disability and even death.

\section{Method}

This study was an observational study. The research design used was a cross-sectional study. This research was conducted on informal sector metal coating workers in Talang District, Tegal Regency. The research sample was a total population taken purposively as many as 35 metal coating workers with criteria of working for more than 1 year and had never changed jobs.

\section{Results and Discussions}

Table 1. Workers Characteristics and Lung Capacity

\begin{tabular}{|c|c|c|c|c|c|}
\hline variables & $\begin{array}{c}\mathrm{n} \\
(\%)\end{array}$ & $\begin{array}{l}\text { mea } \\
\mathrm{n}\end{array}$ & $\begin{array}{l}\text { media } \\
\text { n }\end{array}$ & SD & $\begin{array}{l}\min - \\
\max \end{array}$ \\
\hline $\begin{array}{l}\text { Age } \\
\geq 40 \text { years } \\
<40 \text { years }\end{array}$ & $\begin{array}{l}15(42.9) \\
20(57.1)\end{array}$ & $\begin{array}{c}39.6 \\
9\end{array}$ & 39.00 & 6.29 & $25-56$ \\
\hline $\begin{array}{l}\text { Working } \\
\text { Period } \\
\geq 19 \text { years } \\
<19 \text { years }\end{array}$ & $\begin{array}{l}18(51.5) \\
17(48.5)\end{array}$ & $\begin{array}{c}18.8 \\
6\end{array}$ & 19.00 & 7.19 & $6-40$ \\
\hline $\begin{array}{l}\text { Nutrition } \\
\text { Status(IMT) } \\
\text { Skinny } \\
\text { Normal } \\
\text { Fat }\end{array}$ & $\begin{array}{c}3(8.6) \\
19(54.3) \\
13(37.1)\end{array}$ & $\begin{array}{c}23.0 \\
4\end{array}$ & 23.01 & 3.82 & $\begin{array}{l}15.91- \\
34.23\end{array}$ \\
\hline $\begin{array}{l}\text { FEV1/FVC } \\
\text { Obstruction } \\
\text { Restriction } \\
\text { Medium } \\
\text { Obstruction } \\
\text { Light } \\
\text { Obstruction }\end{array}$ & $\begin{array}{l}1(2.9) \\
1(2.9) \\
2(5.7)\end{array}$ & $\begin{array}{l}84 . \\
4\end{array}$ & 85.93 & 9.02 & $\begin{array}{l}55.25- \\
100.00\end{array}$ \\
\hline $\begin{array}{l}\text { Medium } \\
\text { Obstruction } \\
\text { Light } \\
\text { Obstruction } \\
\text { Normal }\end{array}$ & $\begin{array}{c}1(2.9) \\
6(17.1) \\
24(68.6)\end{array}$ & & & & \\
\hline $\begin{array}{l}\text { Chromium } \\
\text { levels in } \\
\text { urine } \\
\geq 10.13 \\
\mathrm{~g} / \mathrm{L} \\
<10.13 \\
\mathrm{~g} / \mathrm{L}\end{array}$ & $\begin{array}{l}18(51.4) \\
17(48.6)\end{array}$ & $\begin{array}{c}21.3 \\
8\end{array}$ & 10.13 & $\begin{array}{c}30.8 \\
9\end{array}$ & $\begin{array}{c}3.50- \\
145.34\end{array}$ \\
\hline
\end{tabular}

From the result of the study as many as $31.4 \%$ of workers included in the function of abnormal lung capacity.

The levels of chromium in the urine of workers in this study had a minimum value of $3.50 \mathrm{~g} / \mathrm{L}$ and a maximum value of 145,340 $\mathrm{g} / \mathrm{L}$. This should get special attention because it is far above the threshold value of $\mathrm{Cr}$ levels in urine (amounting to $0.05 \mathrm{~g} / \mathrm{l}$ ), the higher the exposure workers receive, the higher the risk of workers experiencing health problems.
Table 2. Age, Working Period, Nutrition Status, Chromium Level in Urine, and the Lung Function Capacity of Metal Coating Workers in Talang, Tegal, 2018

\begin{tabular}{|c|c|c|c|c|c|}
\hline \multirow{3}{*}{ Variables } & \multicolumn{4}{|c|}{ Lung Function Capacity } & \multirow{3}{*}{$p$ value } \\
\hline & \multicolumn{2}{|c|}{ Abnormal } & \multicolumn{2}{|c|}{ Normal } & \\
\hline & f & $\%$ & f & $\%$ & \\
\hline \multicolumn{5}{|l|}{ Age } & \multirow{3}{*}{0.467} \\
\hline$\geq 40$ years & 6 & 40.0 & 9 & 60.0 & \\
\hline$<40$ years & 5 & 25.0 & 15 & 75.0 & \\
\hline \multicolumn{5}{|l|}{$\begin{array}{l}\text { Working } \\
\text { Period }\end{array}$} & \multirow{3}{*}{1.000} \\
\hline$\geq 19$ years & 6 & 33.3 & 12 & 66.7 & \\
\hline$<19$ years & 5 & 29.4 & 12 & 70.6 & \\
\hline \multicolumn{5}{|l|}{$\begin{array}{l}\text { Nutrition } \\
\text { Status(IMT) }\end{array}$} & \multirow{4}{*}{0.013} \\
\hline Skinny & 0 & 0.0 & 3 & 100.0 & \\
\hline Normal & 10 & 52.6 & 9 & 47.4 & \\
\hline Fat & 1 & 7.7 & 12 & 92.3 & \\
\hline \multicolumn{5}{|l|}{$\begin{array}{l}\begin{array}{l}\text { Chromium } \\
\text { levels in urine }\end{array} \\
\end{array}$} & \multirow{3}{*}{0.909} \\
\hline$\geq 10,13 \mathrm{~g} / \mathrm{L}$ & 5 & 27.8 & 13 & 72.2 & \\
\hline$<10,13 \mathrm{~g} / \mathrm{L}$ & 6 & 35.3 & 11 & 64.7 & \\
\hline
\end{tabular}

Based on the results of the Chi-Square statistical test for age analysis with lung function capacity, the Fisher exact value was obtained with a significance level of $95 \%$ of 0.467 ( $p>0.05$ ). It can be concluded that there was no relationship between age and lung function capacity in metal coating workers.

As age increases, it is at risk of a decrease in lung function capacity. Someone with the age of 30 years and over has pulmonary function capacity with an average of $3,000 \mathrm{ml}$ to $3,500 \mathrm{ml}$ while in someone who starts entering the age of 50 years and above the lung capacity will decrease to below 3,000 $\mathrm{ml}$. The source of energy needs for a person will decrease after the age of 40 because at this age there is a decrease in physical strength. This can also affect lung frequency and capacity. At the age of 40 years, energy requirements will decrease, due to decreased physical strength and physiological functions [7].

Physiologically in elderly people, there is an increase in the volume of residual air in the most peripheral airways due to dysfunction of elastic alveolar fibers and terminal bronchioles. Because the total lung capacity is constant, the increase in residual air volume will result in decreased air through maximal respiration resulting in vital lung capacity not optimal [8]. Research in India about car spray paint workers found that there was no relationship between the age of workers and FEV1 / FVC [9]. This research was in line with this study because based on the results of statistical tests it was found that there was no relationship between age and lung function capacity in metal coating workers in TalangTegal. The majority of workers aged less than the same as 40 years are $57.1 \%$ so there are still many workers who have not been affected by lung capacity disorders.

There was no significant relationship between working period and lung function capacity, even though they had worked for quite a long time. This may be due to workers doing their work in an open space so that air exchange contributes to reducing inhaled chrome vapor. The presence of abnormal lung function in workers who work 
long periods of time can lead to many lung diseases that were adapted to lung conditions.[10]

In the results of the Chi-Square statistical test, Pearson scores were obtained with a $95 \%$ significance level of 0.013 ( $\mathrm{p}<0.05)$. It can be concluded that there is a relationship between nutritional status and lung function capacity in metal coating workers.

Increased IMT needs to be considered because it can be used to see the effects on one's respiratory function. IMT can have a significant effect on lung volume and the greatest effect occurs on residual functional capacity and expiratory reserve volume [11].

A person's nutritional status can affect vital lung capacity. Tall thin people usually have a higher lung capacity than short fat people and excessive nutritional status, with the presence of fat deposits can reduce compliance of the chest wall and lungs so that ventilation of the lungs will be disrupted due to decreased lung vital capacity. People who have normal nutritional status have adequate nutrition for the body's metabolism and will be able to quickly repair lung cells [12].

The results of the Chi-Square statistical test obtained Fisher Exact value with a significance level of $95 \%$ of 0.909 ( $p>0.05$ ). It can be concluded that there is no relationship between the levels of chromium in urine and lung function capacity in metal coating workers.

Workers are exposed to chromium through inhalation. Inhalation of short-term exposure to chromium (IV) can cause respiratory problems such as shortness of breath, coughing, sneezing, septal perforation and ulceration, bronchitis, decreased lung function, pneumonia, asthma, itching and pain in the nose ${ }^{10}$ while in the long term can cause pulmonary fibrosis and lung cancer ${ }^{11}$

\section{Conclusion}

Nutritional status has a significant relationship with lung function capacity of electroplating workers. There was no relationship between age, years of service, and levels of chromium in urine with pulmonary function capacity ( $\mathrm{p}>$ $0.05)$.

Metal coating businessmen should pay attention to the safety and health aspects of workers by placing electroplating tubs not against the wind direction to reduce the effects of exposure and provide personal protective equipment for their employees. To monitor the health of workers, periodic lung examinations should be conducted at least once a year.

We would like to express our gratitude to Public HealthFaculty, Diponegoro University for funding this research. And also we would like to express our appreciation to all of the study participants and data collectors for their dedication during the data collection.

\section{References}

1. Gambelunghe, A., , R. Piccinini R, M. Ambrogi, M. Villarini , M. Moretti, C. Marchetti, G. Abbritti, G. Muzi, Primary DNA damage in chrome-plating workers, Toxicology 188, 187-195 (2003)
2. Holmes, A.L., Wise, S.S., Wise Sr., J.P., Carcinogenicity of hexavalent chromium, Indian J. Med. Res.128, 353-372 (2008)

3. Eastmond D.A., Macgregor J.T., Slesinski R.S., Trivalent chromium : assessing the genotoxic risk of an essential trace element and widely used human and animal nutritional supplement, Crit Rev. Toxicol, 38 :173-190 (2008)

4. Zens, C., Dickerson B, Occupational Medicine $3^{\text {rd }}$ ed, Chapter 35 : Chromium and it's compound. Missouri : Mosby (1994)

5. Shrivastava, R. , R.K. Upreti, P.K. Seth, U.C. Chaturvedi, Effects of chromium on the immune system, FEMS Immunology and Medical Microbiology, 34 , 1-7 (2002)

6. Agency for Toxic Subtances and Disease Registry (ATSDR), Toxicological Profile for Chromium, US Department of Health Human Services, Public Health Service .Agency for Toxic substances and Disease Registry, Atlanta (2012)

7. Syarifudin, Anatomy of Nursing Physiology, EGC, Jakarta (2006)

8. Guyton AC., Hall JE., Buku Ajar Fisiologi Kedokteran Edisi ke II, Jakarta, Penerbit Buku Kedokteran. EGC; p. 495-499 (2010)

9. Gupta, Geetika, et al., Forced vital capacity, forced expiratory volume in 1st second and forcedexpiratory ratio in automobile spray paint workers, International Journal of Research in Medical Sciences. Sep; 4(9): 3724-3728 (2016)

10. Sholihah,M.,\&Tualeka, Studi Fatal paru dan Kebiasaan Merokok pada Pekerja yang TerpajanDebupada Perusahaan Konstruksi di Surabaya, The Indonesian Journal of Occupational Safety and Health. 4(1): 1-10 (2010)

11. M. Bottai. et al., Longitudinal changes of body mass index, spirometry and diffusion in a general population, European Respiratory Journal (2002)

12. Supariasa, I DewaNyoman, dkk., Penentuan Status Gizi, Jakarta: EGC (2001) 